\title{
Different concentrations of berberine result in distinct cellular localization patterns and cell cycle effects in a melanoma cell line
}

\author{
Teresa L. Serafim • Paulo J. Oliveira • Vilma A. Sardao • \\ Ed Perkins $\cdot$ Donna Parke $\cdot$ Jon Holy
}

Received: 17 April 2007 / Accepted: 3 July 2007 / Published online: 28 July 2007

(C) Springer-Verlag 2007

\begin{abstract}
Purpose Natural products represent a rich reservoir of potential small molecule inhibitors exhibiting antiproliferative and tumoricidal properties. An example is the isoquinoline alkaloid berberine, which is found in plants such as goldenseal (Hydrastis canadensis). Studies have shown that berberine is able to trigger apoptosis in different malignant cell lines, and can also lead to cell cycle arrest at sub-apoptotic doses. A particularly interesting feature of berberine is the fact that it is a fluorescent molecule, and its uptake and distribution in cells can be studied by flow cytometry and epifluorescence microscopy. To test the relationships between berberine uptake, distribution and cellular effect in melanoma cells, K1735-M2 mouse and WM793 human melanoma cells were treated with different concentrations of berberine, and alterations in cell cycle progression, DNA synthesis, cell proliferation, and cell death measured.

Methods Cell proliferation was measured by sulforhodamine B assays, cell death by flow cytometry, berberine uptake and distribution by laser scanning confocal microscopy and flow cytometry, cell cycle progression by flow
\end{abstract}

T. L. Serafim · P. J. Oliveira · V. A. Sardao

Center of Neurosciences and Cellular Biology,

Department of Zoology, University of Coimbra,

P3004-597 Coimbra, Portugal

E. Perkins · D. Parke

Department of Biochemistry and Molecular Biology,

University of Minnesota, School of Medicine, Duluth,

1035 University Avenue, Duluth, MN 55812, USA

J. Holy ( $\bowtie)$

Department of Anatomy, Microbiology and Pathology,

University of Minnesota School of Medicine, Duluth,

1035 University Avenue, Duluth, MN 55812, USA

e-mail: jholy@d.umn.edu cytometry, and DNA synthesis, M-phase, and mitochondrial effects by immunolabeling and epifluorescence microscopy methods.

Results In these melanoma cell lines, berberine at low doses $(12.5-50 \mu \mathrm{M})$ is concentrated in mitochondria and promotes $\mathrm{G} 1$ arrest. In contrast, higher doses (over $50 \mu \mathrm{M}$ ) result in cytoplasmic and nuclear berberine accumulation, and G2 arrest. DNA synthesis is not markedly affected by low doses of berberine, but $100 \mu \mathrm{M}$ is strongly inhibitory. Even at $100 \mu \mathrm{M}$, berberine inhibits cell growth with relatively little induction of apoptosis.

Conclusion Berberine displays multiphasic effects in these malignant cell lines, which are correlated with the concentration and intracellular distribution of this alkaloid. These results help explain some of the conflicting information in the literature regarding the effects of berberine, and suggest that its use in clinical development may be more as a cytostatic agent than a cytotoxic compound.

Keywords Berberine $\cdot$ Mitochondria Cell cycle . DNA synthesis · Drug localization

\section{Introduction}

Berberine is an isoquinoline alkaloid present in a number of plant species that have long histories of use in ayurvedic, unani, Chinese, and native American traditional medicine practices $[1,2]$. Berberine has been associated with a wide variety of biological effects, including anti-microbial, antiinflammatory, anti-diarrheal, anti-nociceptive and antipyretic activities. It has been reported to lower cholesterol, control blood sugar levels, and function as an anti-oxidant. Recently, it has garnered considerable attention as a possible chemotherapeutic drug for cellular proliferative diseases 
such as psoriasis and cancer (reviewed in [3, 4]). A popular source of berberine and other isoquinoline alkaloids is the plant Hydrastis canadensis, or goldenseal. Goldenseal has been reported to be one of the five top-selling herbal products in the US (http://www.nlm.nih.gov/medlineplus/druginfo/natural/patient-goldenseal.html), and, along with ginseng, is one of the most over-harvested plants in the US [5]. Consequently, there are a number of compelling reasons to study the actions, including possible harmful side effects, of berberine and related alkaloids.

A growing number of studies are focusing on the ability of berberine to function as an anti-cancer drug through its ability to induce apoptosis in a number of different malignant cell lines. Berberine has been reported to induce apoptosis through a mitochondrial pathway that includes upregulation of $\mathrm{p} 53$, alterations in $\mathrm{Bcl}-2 / \mathrm{Bax}$ ratios, a decrease in mitochondrial membrane potential, release of cytochrome $c$, and activation of caspases [2, 6-12]. This is of particular interest in light of studies demonstrating a mitochondrial localization of berberine, raising the possibility that apoptosis results from mitochondrial damage induced by berberine. Alternatively, berberine also binds DNA and RNA (reviewed in Ref. [3]), and apoptosis may be triggered downstream of a DNA damage response. To investigate these questions in more detail, we treated K1735-M2 melanoma cells with different concentrations of berberine for various lengths of time and correlated berberine localization patterns with effects on cell proliferation, cell cycle progression, and cell death. The results of these studies indicate that the primary effect of berberine in these cells is cytostatic rather than cytotoxic, and that the inhibition of cell proliferation reflects a multiphase response to berberine that is associated with concentration-dependent differences in localization patterns.

\section{Materials and methods}

\section{Cell culture}

K1735-M2 mouse melanoma cells (the kind gift of Dr Lillian Repesh, Department of Anatomy, Microbiology, and Pathology, University of Minnesota School of Medicine, Duluth, MN, USA) and WM793 human vertical growth phase melanoma cells (the kind gift of Dr Meenhard Herlyn, Wistar Institute, Philadelphia, PA, USA) were grown in Dulbecco's modified Eagle's medium (GIBCO, Grand Island, NY, USA) and 10\% Fetal Clone III (FC3; HyClone, Logan, UT, USA) in a $5 \% \mathrm{CO}_{2}$ atmosphere at $37^{\circ} \mathrm{C}$. Cells were passaged by trypsinization using standard methods; all experiments were seeded from cultures in log-phase growth.
Cell proliferation measurements

Sulforhodamine B assays [13] were conducted to measure the effects of berberine on the proliferation of M2 cells, essentially as described by Holy et al. [14]. Cells were seeded at a concentration of $1 \times 10^{4}$ cells $/ \mathrm{ml}$ in 24 -well plates, and allowed to recover for 1 day prior to drug addition. Stock solutions of $25 \mathrm{mM}$ berberine chloride (Sigma Chemical Co., St Louis, MO, USA) were prepared in dimethylsulfoxide (DMSO) and stored frozen; for experiments, aliquots were thawed and diluted into culture medium at the desired concentration. Vehicle controls received an equivalent amount of DMSO only. After sulforhodamine labeling, absorbance was measured in a spectrophotometer at $540 \mathrm{~nm}$; the amount of dye released is proportional to the number of cells present in the dish, and is a reliable indicator of cell proliferation.

\section{Cell death assays}

After berberine or DMSO (vehicle only control) treatment, culture media was collected from the samples and saved. Cells were trypsinized, and added back to the saved media in order to collect both adherent cells as well as non-adherent (dead and dying) cells floating in the media. Cells were collected by centrifugation and resuspended in PBS containing 5\% fetal bovine serum. Components of the live/dead kit (calcein-AM and ethidium homodimer; Molecular Probes, Eugene, OR, USA) were added according to manufacturer's instructions, and cells incubated at $37^{\circ} \mathrm{C}$ for $15 \mathrm{~min}$. The FL1 (calcein, green) signal and FL3 (ethidium, red) signal were measured with a Becton-Dickenson FACScalibur flow cytometer. The red-fluorescing cells were discriminated from the greenfluorescing cells and counted using the cytometer Cell Quest software package.

\section{Measurement of berberine uptake}

For time-course studies, berberine was added to $100 \mu \mathrm{M}$ to dishes of M2 cells 360, 300, 240, 180, 120, 60 and 30 min prior to harvesting by trypsinization. Cells were resuspended in PBS-5\% FC3, and immediately measured with a Becton-Dickenson flow cytometer, using the FL1 filter set. For dose-response studies, a range of berberine concentrations $(12.5-150 \mu \mathrm{M})$ was added to dishes of M2 cells $2.5 \mathrm{~h}$ prior to trypsinization, resuspension in PBS-5\% FC3, and measurement with the flow cytometer. For all samples, approximately $15 \mathrm{~min}$ had elapsed between removal of berberine-containing culture media and the measurement of berberine fluorescence intensity. 
Confocal microscopy of berberine localization

Cells were seeded into $35 \mathrm{~mm}$ glass-bottom petri dishes (MatTek Inc., Amherst, MA, USA) at a density of $1 \times 10^{4}$ / $\mathrm{ml}$, and allowed to recover for $24 \mathrm{~h}$ prior to use. A range of concentrations of berberine was added to the dishes; after $2 \mathrm{~h}$, the dishes were removed from the incubator and placed on the stage of a Nikon C1 laser-scanning confocal microscope. Laser excitation and PMT gain were set at values to best visualize the range of fluorescence emitted by cultures treated with $12.5-150 \mu \mathrm{M}$ berberine. Berberine fluorescence was imaged using a Spectra Physics Krypton-Argon Model $163 \mathrm{C}$ polarized laser $(40 \mathrm{~mW}$ at $488 \mathrm{~nm})$ and a $545 \mathrm{~nm}$ dichroic long pass, with a $605 / 75$ band pass for the red channel (PMT 2). For documentation purposes, this red signal was converted to green using image-processing methods, in order to reveal better morphological detail. All pictures were obtained and processed using identical settings in order to directly compare differences in fluorescence intensity or localization patterns.

\section{Cell cycle analysis}

Cells in log-phase growth were treated with different concentrations of berberine for various lengths of time, trypsinized, resuspended, and fixed with cold $\left(-10^{\circ} \mathrm{C}\right) 70 \%$ ethanol. Cells were subsequently washed in PBST and resuspended in $0.5 \mathrm{ml}$ PBST containing $20 \mu \mathrm{g} / \mathrm{ml}$ RNase, and incubated at $37^{\circ} \mathrm{C}$ for $45 \mathrm{~min}$. Propidium iodide was added to $20 \mu \mathrm{g} / \mathrm{ml}$, and cells stained for $30 \mathrm{~min}$ at $37^{\circ} \mathrm{C}$. DNA quantity was measured using a Becton-Dickenson FACScalibur flow cytometer (BD Biosciences, San Jose, CA, USA). The percentage of cells in G1, S and G2/M in each sample was determined using Modfit LT software (Verity Software House, Topsham, ME, USA). In some experiments, FCCP (carbonyl cyanide 4-(trifluoromethoxy)phenylhydrazone) (Sigma Chem. Co.) was added to $10 \mu \mathrm{M}$, with or without berberine. Control cultures received an equivalent amount of vehicle (DMSO) only, which never exceeded $0.1 \% \mathrm{v} / \mathrm{v}$.

M-phase quantitation

To quantitate the percentage of cells in M-phase, M2 cells were seeded onto glass coverslips and grown in the presence of $100 \mu \mathrm{M}$ berberine (or an equivalent amount of DMSO only) for $24 \mathrm{~h}$. Cells were then fixed in freezer-temperature absolute methanol, and subsequently immunolabeled using a monoclonal antibody to $\beta$-tubulin (E7; Developmental Studies Hybridoma Bank, Iowa City, IA, USA), followed by a goat-anti-mouse-Texas Red secondary antibody (Jackson Immunoresearch, Malvern, PA, USA). Chromatin was counterstained by adding Hoechst 33258
(Sigma Chem. Co.) to the secondary antibody at $5 \mu \mathrm{g} / \mathrm{ml}$. Cells were examined by epifluorescence microscopy to identify M-phase cells, which were easily identifiable as rounded cells containing mitotic spindles and condensed chromatin. For quantitation, random fields of view were selected, and both the total number of cells and the number of M-phase cells counted. At least five fields of view were counted for each sample, with a total of 500 cells counted per sample.

\section{BrdU labeling}

At various time points after the addition of berberine (or DMSO vehicle only), cells were pulse-labeled with $10 \mu \mathrm{M}$ bromodeoxyuridine (BrdU; Sigma Chem. Co.) for $30 \mathrm{~min}$ and then fixed in cold $\left(-10^{\circ} \mathrm{C}\right)$ absolute methanol. For BrdU labeling, cells were rehydrated with PBST and treated with $2 \mathrm{~N} \mathrm{HCl}$ for $20 \mathrm{~min}$ at room temperature. Cells were then washed five times with PBST, and incubated in PBST containing $0.5 \%$ non-fat powdered milk for $30 \mathrm{~min}$ at $37^{\circ} \mathrm{C}$. Cells were immunolabeled and counterstained with Hoechst as described above, using a labeled anti-BrdU antibody (G3G4, Developmental Studies Hybridoma Bank).

\section{Evaluation of mitochondrial effects of berberine}

K1735-M2 and WM793 cells were seeded in 35 mm glassbottom petri dishes as described above, and subsequently treated with either $25 \mu \mathrm{M}$ berberine or vehicle only $(0.1 \%$ DMSO) for $6 \mathrm{~h}$. Hoechst 33342 (Sigma) and tetramethylrhodamine methyl ester (TMRM; Invitrogen Corp., Carlsbad, CA, USA) were added to $2 \mu \mathrm{g} / \mathrm{ml}$ and $100 \mathrm{nM}$, respectively, and the dishes incubated for $30 \mathrm{~min}$ prior to examination by epifluorescence microscopy. All TMRM images from control and berberine-treated samples were taken at the same exposure times and processed identically in order to compare fluorescence intensities.

\section{Results}

Effect of berberine on cell proliferation

The effects of a range of concentrations of berberine (5$100 \mu \mathrm{M})$ on cell proliferation was measured for up to 6 days (Fig. 1). Sulforhodamine B assays demonstrate that a single application of berberine leads to a significant and dose-dependent inhibition of M2 proliferation over a number of days at concentrations as low as $5 \mu \mathrm{M}$ (Fig. 1a). About $50 \mu \mathrm{M}$ berberine was strongly cytostatic, and $100 \mu \mathrm{M}$ completely inhibited cell proliferation (Fig. 1b). Microscopic examination of these cultures revealed few 

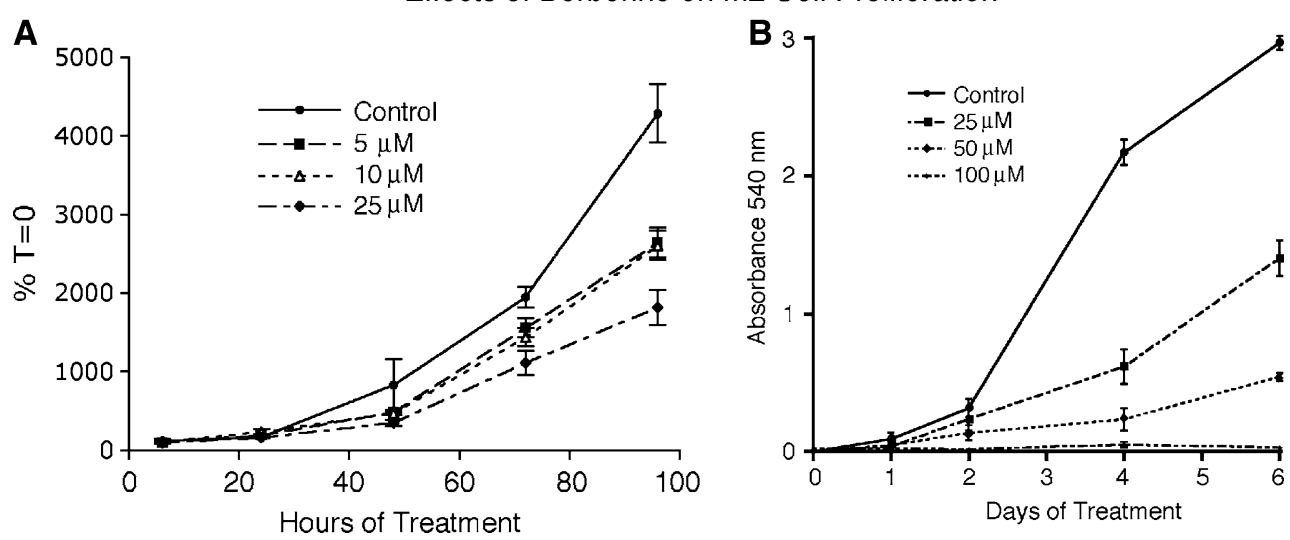

Fig. 1 Sulforhodamine B (SRB) proliferation assays of M2 cells exposed to berberine. a Cells treated with 5,10 or $25 \mu \mathrm{M}$ berberine, or vehicle (DMSO) only (control). Proliferation was measured at 6, 24, 48,72 and $96 \mathrm{~h}$ after the addition of berberine. Note the dose-dependent inhibition of cell proliferation. $\mathbf{b}$ SRB assay showing the effects of up to $100 \mu \mathrm{M}$ berberine on cell proliferation. Proliferation was measured 1, 2, 4 and 6 days after the addition of 25,50 or $100 \mu \mathrm{M}$ berberine, or vehicle (DMSO) only (control). The reduction in the slope of the control between days 4 and 6 is due to the fact that the sample wells

dead cells floating in the media at concentrations of berberine up to $50 \mu \mathrm{M}$, and modest numbers of dead cells in the $100 \mu \mathrm{M}$ cultures. Quantitation of cell death by two different measures (loss of plasma membrane integrity, Fig. 2, and appearance of cells with a sub-G1 DNA content, Fig. 5) supports these observations; up to $50 \mu \mathrm{M}$ berberine triggers very little M2 cell death, and only a low level of cell death is apparent after exposure to $100 \mu \mathrm{M}$ berberine for $48 \mathrm{~h}$ (Figs. 2, 5). These results demonstrate that berberine has significant cytostatic effects, but is cytotoxic to these cells only at very high concentrations.

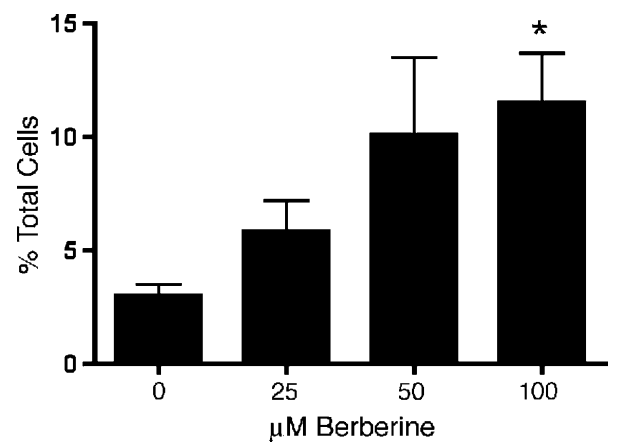

Fig. 2 Graph showing only modest increases in cell death in M2 cultures treated with up to $100 \mu \mathrm{M}$ berberine for $48 \mathrm{~h}$. Shown is the percentage of cells with compromised plasma membranes, as detected with ethidium homodimer staining and flow cytometry. The values reflect the averages of three independent experiments; the bars indicate the standard error of the mean. Only the $100 \mu \mathrm{M}$ cultures displayed a significant increase in the amount of cell death at this time point (asterisks; $p<0.05)$ were becoming confluent with cells, thus slowing their proliferative rate. Twenty-five micromole berberine slows proliferation, $50 \mu \mathrm{M}$ strongly inhibits it, and no increase in cell numbers occur in cultures treated with $100 \mu \mathrm{M}$ berberine. Both graphs reflect data from three independent experiments; bars indicate standard error of the mean. For a, significant differences between the control and $25 \mu \mathrm{M}$ groups are present $(p<0.05)$; the 5 and $10 \mu \mathrm{M}$ groups are not different from each other, but their values lie between the control and the $25 \mu \mathrm{M}$ groups $(p<0.05)$

Uptake and compartmentalization of berberine

Because berberine is a fluorescent compound that can be detected by both epifluorescence microscopy and flow cytometry, we measured the uptake and distribution of berberine in living M2 cells using these methods. Measurements of total cellular fluorescence by flow cytometry showed that $100 \mu \mathrm{M}$ berberine took between 1 and $2 \mathrm{~h}$ to accumulate to a maximum level within cells, and this level was quite stable for at least $6 \mathrm{~h}$ (Fig. 3a). The half-maximal value was achieved within $30 \mathrm{~min}$, which correlates well with the appearance of mitochondrial berberine fluorescence by microscopy (see below). Comparison of the fluorescence levels of different concentrations of berberine at a $2.5 \mathrm{~h}$ time point demonstrates that an essentially linear uptake of berberine occurs between 12.5 and $150 \mu \mathrm{M}$ (the extent of the range tested; Fig. 3b). The effect of FCCP on the uptake of different concentrations of berberine was also examined. Addition of FCCP had little effect on the uptake of $50 \mu \mathrm{M}$ or less berberine after $2 \mathrm{~h}$, but significantly increased the berberine signal in cultures treated with $100 \mu \mathrm{M}$ or more (Fig. 3c).

Confocal microscopy demonstrates that the different concentrations of berberine exhibit different intracellular distribution patterns of fluorescent signals. Low concentrations of berberine (e.g., $12.5 \mu \mathrm{M}$ or less) are not readily detectable within $\mathrm{M} 2$ cells at the gain settings used to avoid grossly oversaturating the signal emitted by higher concentrations of berberine. On the other hand, strong mitochondrial fluorescence is apparent in cells treated with 25 or 

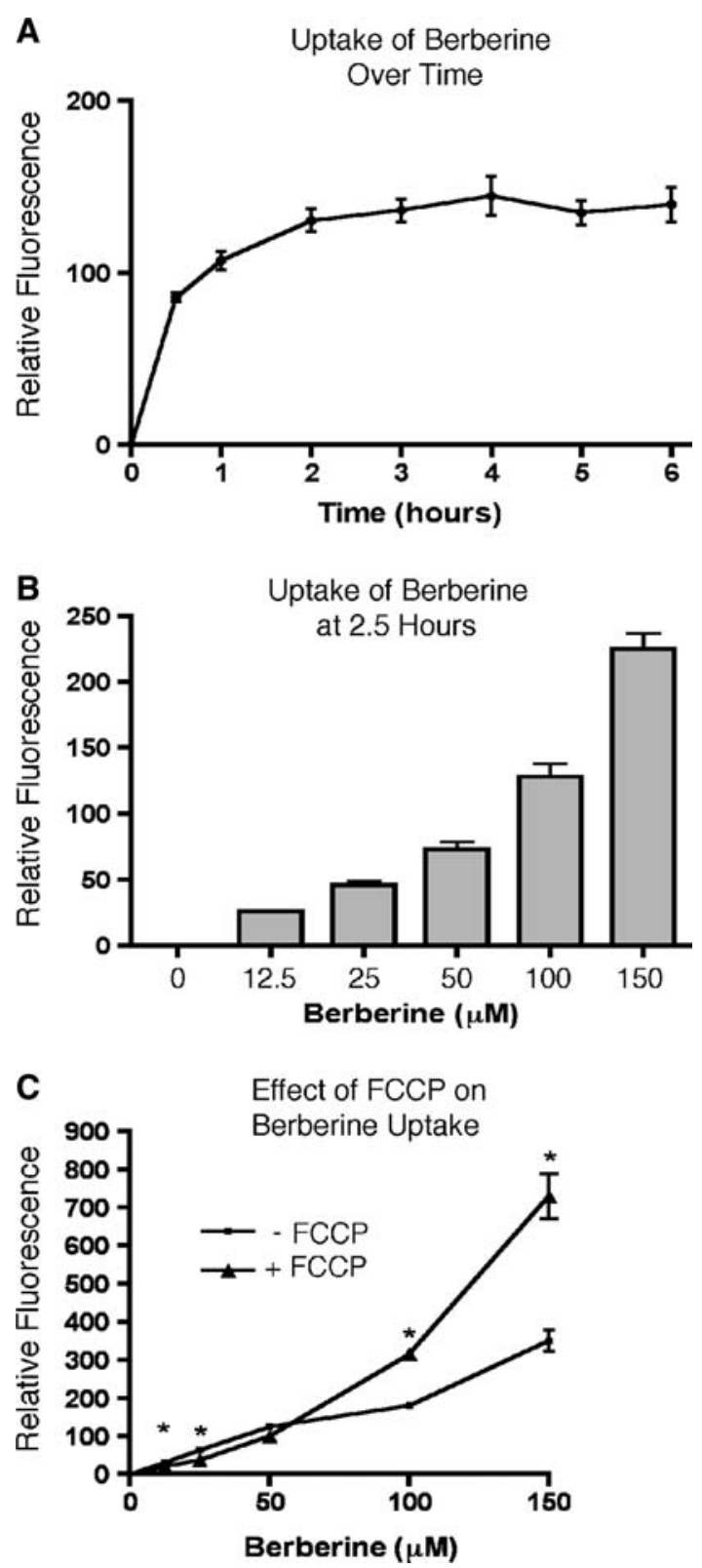

Fig. 3 Cellular uptake of berberine, measured by flow cytometry. a Uptake profile of cultures treated with $100 \mu \mathrm{M}$ berberine. Half-maximal accumulation of berberine occurs in less than $30 \mathrm{~min}$ after addition, with maximal values being achieved about $2 \mathrm{~h}$ after addition. $\mathbf{b}$ Cellular fluorescence values of different concentrations of berberine, measured $2.5 \mathrm{~h}$ after addition. Note the essentially linear increase in fluorescence intensity with increasing berberine concentrations over the range tested. c Effect of the mitochondrial poison FCCP on berberine uptake by M2 cells. The addition of FCCP results in a significantly greater accumulation of higher concentrations berberine in these cells. The data points reflect the average of three independent experiments, and the bars represent the standard error of the mean (asterisks; $p<0.05$ )

$50 \mu \mathrm{M}$ berberine (Fig. 4). This fluorescence becomes noticeable by microscopy after about 20-30 min of incubation, which correlates well with the increase in signal detected by flow cytometry (Fig. 3a). The entire cytoplasm, as well as nuclei and nucleoli, becomes fluorescent in cells incubated in $100 \mu \mathrm{M}$ or more berberine (Fig. 4).

Effects of berberine on the cell cycle

Different berberine concentrations and exposure times result in a number of distinct perturbations in cell cycle progression (Figs. 5, 6). Twenty-five micromole berberine leads to an increase in the percentage of cells in G1, which becomes more pronounced at days 2 and 3 after addition. In contrast, $100 \mu \mathrm{M}$ berberine does not lead to a similar G1 increase, but rather results in a marked increase in the percentage of cells in G2/M. Fifty micromole berberine appears to be intermediate between these patterns in its effects. All concentrations of berberine tested $(25,50$ and $100 \mu \mathrm{M})$ reduce the percentage of cells in S-phase, with a noticeable time-dependence effect for $25 \mu \mathrm{M}$. Because of the possibility that berberine may be interfering with normal mitochondrial function (due to its mitochondrial localization), the pattern of cell cycle disruption of a known mitochondrial poison, FCCP, was compared with that of berberine. Interestingly, $10 \mu \mathrm{M}$ FCCP by itself bore many similarities to the effects of 12.5 and $25 \mu \mathrm{M}$ berberine (Fig. 7). Like these concentrations of berberine, FCCP caused an increase in G1, suppressed S-phase, and had little effect on the percentage of cells in G2/M. Co-treatment with $25 \mu \mathrm{M}$ berberine and $10 \mu \mathrm{M}$ FCCP dampened the increase in G1, and increased the percentage of cells in G2/ $\mathrm{M}$. Therefore, the addition of FCCP to low concentrations of berberine resulted in cell cycle profiles that more resembled those of cells exposed to high concentrations of berberine alone.

To distinguish whether the increase in the number of cells in $\mathrm{G} 2 / \mathrm{M}$ following treatment with $100 \mu \mathrm{M}$ berberine was due to a block in $\mathrm{G} 2$ or M, the number of M-phase cells (cells containing mitotic spindles and condensed chromatin) were counted after a $24 \mathrm{~h}$ exposure. The percentage of cells in M-phase was significantly decreased after treatment, indicating that high concentrations of berberine induce a G2 block prior to entry into M-phase (Fig. 8).

To investigate the time-course of the reduction of cells in S-phase by berberine, M2 cells were treated with berberine, and then pulse-labeled with BrdU. Two hours after berberine addition, BrdU labeling was still observed in control, 25 and $50 \mu \mathrm{M}$ berberine cultures, but the intensity of labeling appeared to be somewhat diminished in the 25 , and especially $50 \mu \mathrm{M}$ cultures (Fig. 9). In contrast, DNA synthesis was significantly reduced in cultures treated with $100 \mu \mathrm{M}$ berberine, although some labeling was still present in these cells. 24 and $48 \mathrm{~h}$ after addition of berberine, BrdU labeling was still present in cultures treated with either 25 or $50 \mu \mathrm{M}$ berberine, but the percentage of cells exhibiting a BrdU signal appears to be diminished. At $96 \mathrm{~h}$ of treatment, some 
Fig. 4 Visualization of fluorescent berberine distribution in M2 cells by laser-scanning confocal microscopy. Cultures were photographed using the same instrument settings, $2 \mathrm{~h}$ after the addition of 12.5-150 $\mu \mathrm{M}$ berberine. $\mathbf{a}, \mathbf{b}$ show the same fields of view of a culture treated with $12.5 \mu \mathrm{M}$ berberine, by differential interference contrast (a, DIC) and fluorescence (b) optics. Berberine fluorescence is very low and can barely be detected (control cultures that received DMSO only as a vehicle control displayed a complete lack of fluorescence: not shown). $\mathbf{c}, \mathbf{d}$ are the same field of view, showing cells treated with $25 \mu \mathrm{M}$ berberine. Note the strong fluorescence of mitochondria, and the lack of appreciable cytoplasmic or nuclear labeling. $\mathbf{e}, \mathbf{f}$ are the same field of view, showing cells treated with $50 \mu \mathrm{M}$ berberine. The fluorescent signal remains restricted to mitochondria. $\mathbf{g}, \mathbf{h}$ are the same field of view, showing cells treated with $100 \mu \mathrm{M}$ berberine. At this concentration, cytoplasm and nuclei (especially the nucleoli) are beginning to fluoresce. $\mathbf{i}$, $\mathbf{j}$ are the same field of view, showing cells treated with $150 \mu \mathrm{M}$ berberine. Note the progressive increase in cytoplasmic and nuclear fluorescence. All images the same magnification; scale bar in b represents $10 \mu \mathrm{m}$
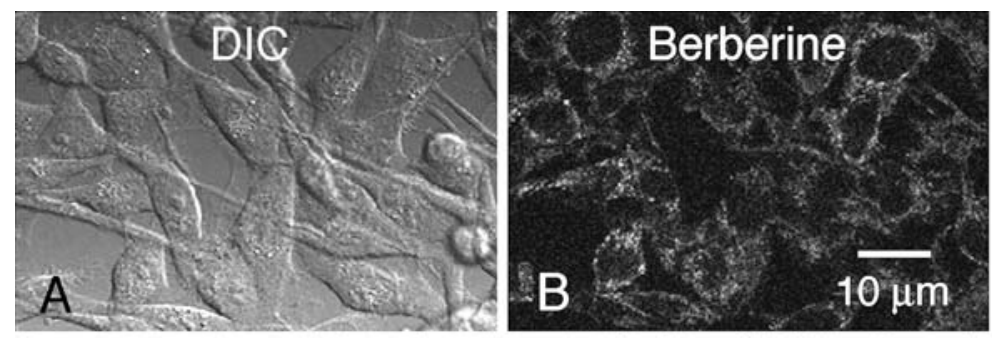

$12.5 \mu \mathrm{M}$
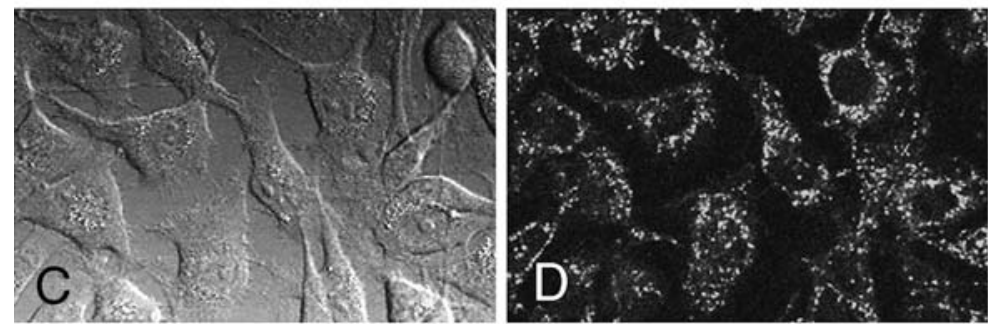

$25 \mu \mathrm{M}$
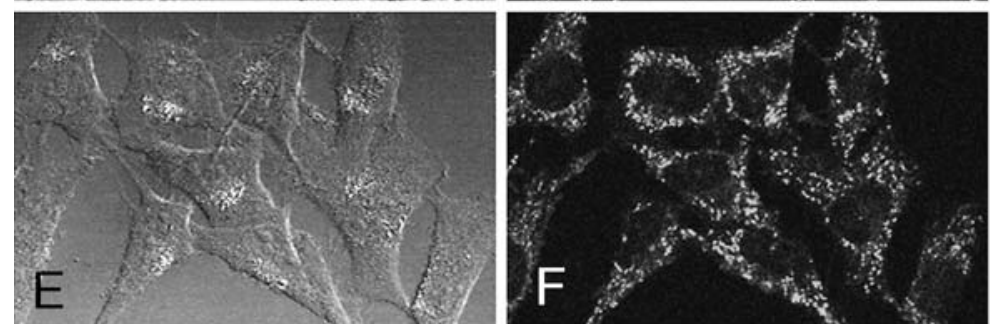

$50 \mu \mathrm{M}$
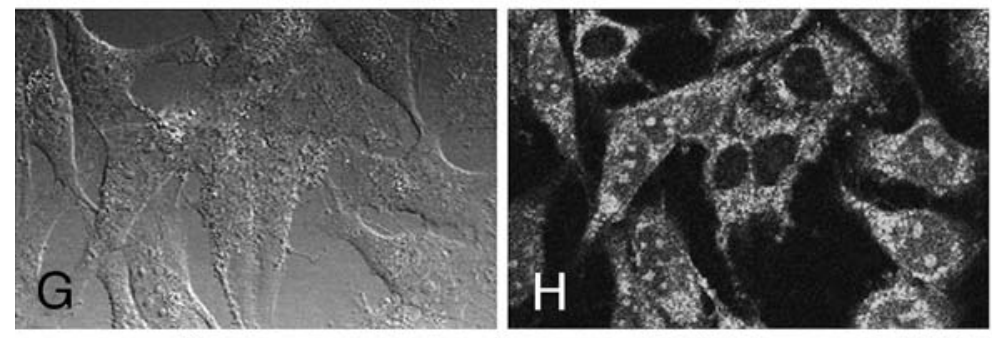

$100 \mu \mathrm{M}$
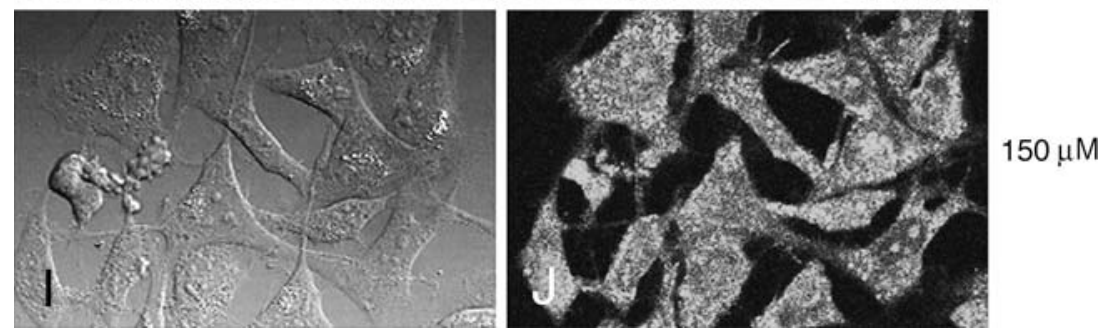

cells are still labeled in the $25 \mu \mathrm{M}$ berberine cultures, but BrdU uptake is essentially totally suppressed in the $50 \mu \mathrm{M}$ cultures. DNA synthesis in the $100 \mu \mathrm{M}$ cultures remained completely inhibited at all of these time points (Fig. 9).

To determine whether the mitochondrial accumulation of lower concentrations of berberine caused perturbations in mitochondrial structure or function, K1735-M2 and WM793 melanoma cells were incubated in $25 \mu \mathrm{M}$ berberine for $6 \mathrm{~h}$, and then labeled with tetramethylrhodamine methyl ester (TMRM), which is a polarization-dependent mitochondrial probe. Berberine treatment led to mitochondrial fragmentation in both of these melanoma cell lines (Fig. 10). In addition, a reduction in mitochondrial TMRM fluorescence intensity was noticeable, indicating that the mitochondrial membrane potential is diminished in the presence of berberine.

\section{Discussion}

Berberine is a fluorescent compound, with absorbance peaks of 230, 267, 344 and $420 \mathrm{~nm}$, and peak emission at $550 \mathrm{~nm}$ [3]. Although it has been utilized as a fluorescent stain for mast cells [15, 16], sperm and oocytes [17], DNA and RNA [18-21], and mitochondria [22], the kinetics of its uptake and distribution in living cells has not been extensively characterized. In this study, 25 and $50 \mu \mathrm{M}$ berberine strongly labeled mitochondria, with little detectable 

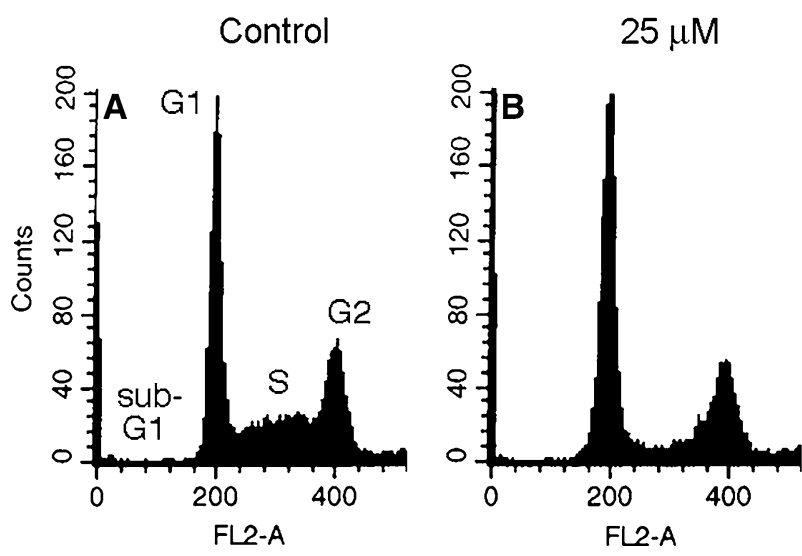

Fig. 5 Histograms of cell cycle distribution of K1735-M2 cells after treatment with vehicle only (control; a), or 25 (b), 50 (c) or 100 (d) $\mu \mathrm{M}$ berberine for $48 \mathrm{~h}$. Shown is a representative example from four separate experiments that were averaged together to obtain the graphs shown in Fig. 6. Note the low numbers of cells in the sub-G1 area, indi-
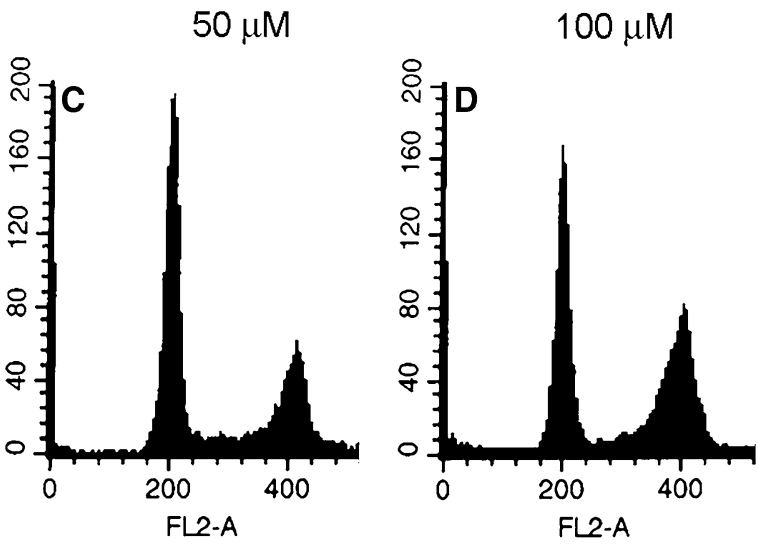

cating that apoptosis is not occurring to a large extent in these cultures. By this method, the percentage of cells with a sub-G1 content of DNA only rose from $0.49 \%$ in controls (a) to $5.5 \%$ in cultures treated with $100 \mu \mathrm{M}$ berberine for $48 \mathrm{~h}$ (d; average of three independent experiments)

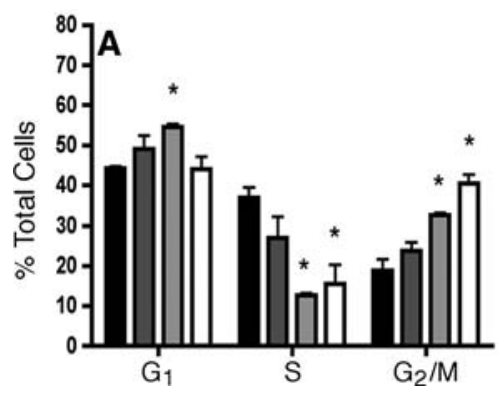

Fig. 6 Cell cycle analysis of cultures treated with 25,50 and $100 \mu \mathrm{M}$ berberine for 24 (a), 48 (b) or 72 (c) h. Twenty-five micromole berberine leads to an increase in the percentage of cells in G1 at all time points, and a decrease in numbers of cells in S-phase at 48 and $72 \mathrm{~h}$. In contrast, $100 \mu \mathrm{M}$ berberine leads to an increase in the percentage of cells in G2, as well as a reduction in the numbers of S-phase cells. The
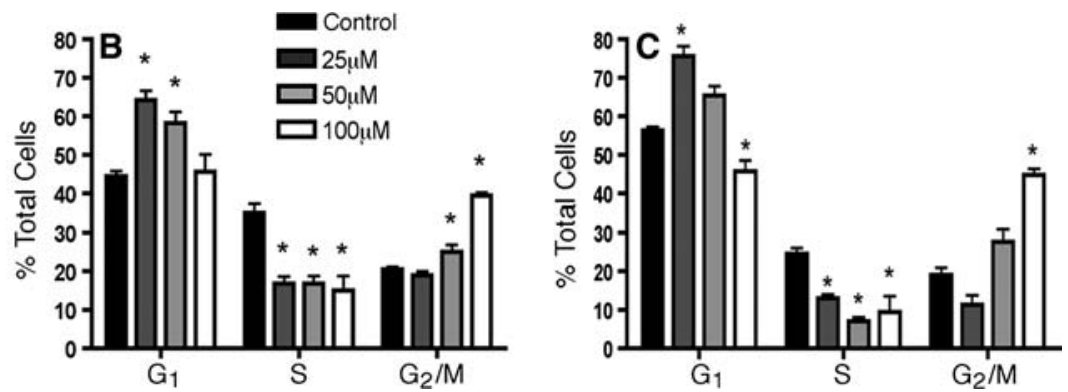

effects of $50 \mu \mathrm{M}$ berberine appears to be intermediate between those of 25 and $100 \mu \mathrm{M}$. The values shown are the averages of three independent experiments; bars indicate the standard error of the mean. Samples identified by asterisks (*) denote a significant difference from controls $(p<0.05)$

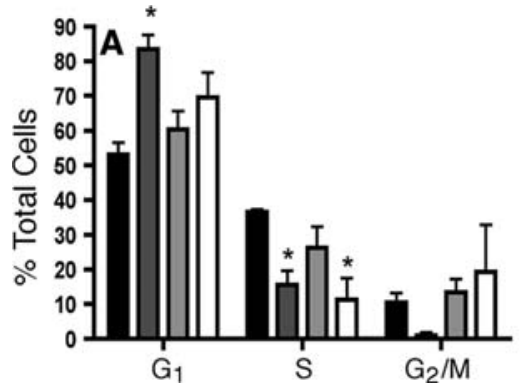

Fig. 7 Comparison of the effects of FCCP with those of berberine on cell cycle progression at 24 (a), 48 (b) and 72 (c) h of drug exposure. Similar to $25 \mu \mathrm{M}$ berberine, $10 \mu \mathrm{M}$ FCCP increases the number of cells in G1, and decreases the percentage of cells in S-phase. Interestingly, neither $25 \mu \mathrm{M}$ berberine nor $10 \mu \mathrm{M}$ FCCP by themselves caused

cytoplasmic or nuclear fluorescence. However, both cytoplasm and nuclei became noticeably fluorescent at higher concentrations of berberine $(100$ and $150 \mu \mathrm{M})$. Previous studies demonstrated that berberine displays a
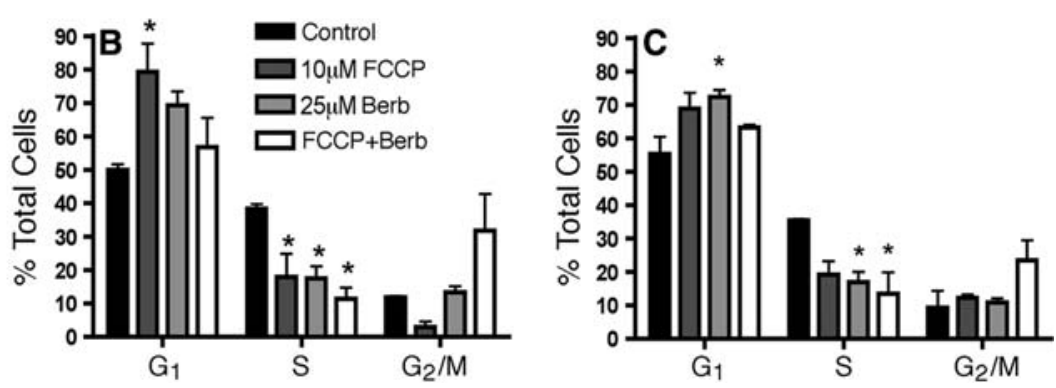

a significant increase in the percentage of cells in G2/M, but a combination of both did. The values shown are the averages of three independent experiments; bars indicate the standard error of the mean. Samples identified by asterisks $(*)$ denote a significant difference from controls $(p<0.05)$

striking increase in fluorescence in the hydrophobic regions of polarized mitochondrial membranes, apparently due to an increase in quantum yield [23]. Although more berberine binds to energized mitochondria than 


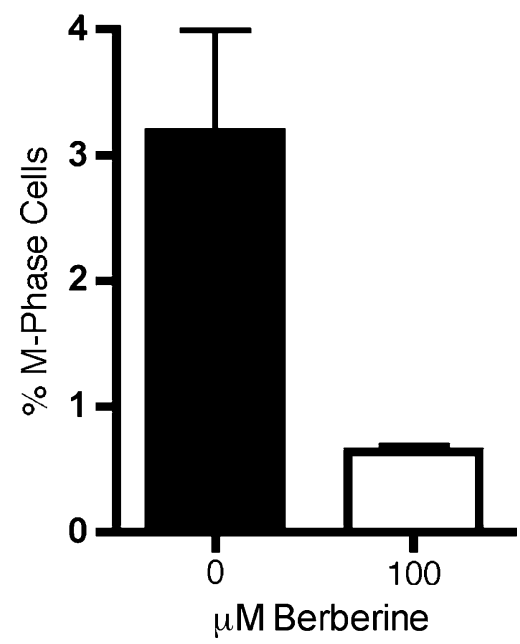

Fig. 8 Comparison of the number of cells in M-phase in control cultures (black bar) and cultures incubated in $100 \mu \mathrm{M}$ berberine for $24 \mathrm{~h}$. A significant reduction in the numbers of cells in M-phase occurs after treatment with this concentration of berberine $(p<0.05)$. The values are averages from three independent experiments; bars indicate standard error of the mean

non-energized mitochondria, this difference has been reported to be relatively minor [23]. Similarly, a dramatic increase in fluorescence quantum yield also occurs upon DNA binding [19]. This behavior complicates the quantitative assessment of berberine localization within cells by fluorescence methods. However, the overall berberine signal in nuclei, which, like mitochondria, would also be expected to display increases in fluorescence quantum yield as berberine binds DNA, is very low in M2 cells treated with 25 and $50 \mu \mathrm{M}$ berberine. Instead, both nucleus and cytoplasm become steadily more fluorescent as the concentration of berberine added to the cultures increases above $50 \mu \mathrm{M}$. Although detailed washout experiments have not been conducted, the cytoplasm and nucleus appear to have affinity for berberine, as the flow cytometry data was obtained from cells that had been washed out of berberine (resuspended in PBS) for approximately $15 \mathrm{~min}$. This conclusion is supported by previous studies reporting staining of nuclei and cytoplasm by berberine [20, 24, 25]. We interpret these results as indicating that most berberine preferentially accumulates in mitochondria at lower concentrations $(<50 \mu \mathrm{M})$, but these binding sites become saturated at higher concentrations $(>50 \mu \mathrm{M})$, and berberine subsequently accumulates in the cytoplasm and nucleus. If this is the case, then two sets of effects could be expected to occur in berberine-treated cells: cells exposed to lower concentrations of berberine would be predicted to display primarily mitochondrial effects, whereas cells exposed to higher concentrations of berberine could additionally exhibit a host of other alterations, including effects resulting from perturbations of DNA organization and function.
Flow cytometry data indicates that total cellular accumulation of berberine did not appear to be saturated at the highest concentration $(150 \mu \mathrm{M})$ used in this study. On the other hand, time-course studies using $100 \mu \mathrm{M}$ berberine indicate that uptake reached a maximum by about $2 \mathrm{~h}$, with about $50 \%$ entering cells within $30 \mathrm{~min}$. Addition of $10 \mu \mathrm{M}$ FCCP significantly enhanced the accumulation of 100 and $150 \mu \mathrm{M}$ berberine in $\mathrm{M} 2$ cells, raising the possibility that berberine is a substrate for drug efflux pumps, and that reduction of ATP levels by FCCP interferes with the export of higher concentrations of berberine. Berberine has been reported to inhibit P-gp activity in a number of transformed cell lines [26], to mildly activate P-gp ATPase activity in brain [27], and to up-regulate the expression of P-gp in oral, gastric, and colon cancer cells [28]. Inhibitors of MDR1 and MRP1, as well as reduction of ATP levels with sodium azide increased the cellular accumulation in human KB3-1 cells [29].

Of course, for clinical relevance, uptake and metabolism of berberine in an in vivo situation must take into account route of delivery and pharmacokinetic considerations. Berberine has been shown to be rapidly absorbed by the small intestine in rats [30], and less than 5\% is eliminated from urine and bile after a bolus i.v. injection [31]. Relatively more metabolites than berberine were recovered from urine of human volunteers after oral ingestion of berberine [32], suggesting that berberine metabolites may play important roles in vivo. Berberine is metabolized by the liver to berberrubine, thalifendine, demethyleneberberine, and jattrorhizine; interestingly, berberrubine and thalifendine inhibit topoisomerases II and I, respectively, and berberrubine has been shown to possess antitumor properties [33-35]. Based on in vitro findings that 1,5 and $10 \mu \mathrm{g} / \mathrm{ml}$ berberine were cytotoxic to B16 mouse melanoma cells, daily i.p. injections of 1,5 and $10 \mathrm{mg} / \mathrm{kg}$ berberine were carried out in an in vivo melanoma transplant model; tumor weights were significantly reduced in the 5 and $10 \mathrm{mg} / \mathrm{kg}$ animals [36]. These findings indicate that the lower concentrations of berberine used in this study are within the range of clinical relevance.

Subjectively, the strong mitochondrial berberine signal suggests that this compound could directly impact mitochondrial function. Previous studies in fact have shown that berberine inhibits NADH dehydrogenase and respiratory activity [23, 37]. In addition, mitochondrial participation in berberine-induced apoptosis has been demonstrated in a number of studies $[2,6,11,38]$. Mitochondrially-relevant effects of berberine exposure include changes in Bcl-2/Bax ratios, reactive oxygen species production, and a reduction in mitochondrial membrane potential $[6,11]$. In this report, we demonstrate that berberine induces mitochondrial fragmentation and diminishes polarization in K1735-M2 and WM793 melanoma cells. We have extended these studies 
Fig. 9 BrdU incorporation in cells treated with different concentrations of berberine for different lengths of time. Hoechst staining identifies all nuclei in the fields of view $(\mathbf{b}, \mathbf{d}, \mathbf{f}, \mathbf{h}, \mathbf{j}$, $\mathbf{l}, \mathbf{n}, \mathbf{p}, \mathbf{r}$ and $\mathbf{t}$ ); BrdU fluorescence identifies those nuclei actively synthesizing DNA $(\mathbf{c}, \mathbf{e}, \mathbf{g}$, $\mathbf{I}, \mathbf{k}, \mathbf{m}, \mathbf{o}, \mathbf{q}, \mathbf{s}$ and $\mathbf{u})$. a-c Control culture, showing many nuclei actively synthesizing DNA (compare $\mathbf{c}$ with b). Also shown is the same field of view by phase contrast optics (a). d-i Cells treated with 25,50 or $100 \mu \mathrm{M}$ berberine for $2 \mathrm{~h}$ prior to BrdU labeling. Cells treated with $25(\mathbf{d}, \mathbf{e})$ and $50 \mu \mathrm{M}(\mathbf{f}, \mathbf{g})$ are still able to incorporate $\mathrm{Br}$ $\mathrm{dU}$, while incorporation is completely inhibited in the $100 \mu \mathrm{M}$ culture $(\mathbf{h}, \mathbf{i})$. j-o Cells treated with 25,50 or $100 \mu \mathrm{M}$ berberine for $48 \mathrm{~h}$ prior to BrdU labeling. Cells treated with 25 and $50 \mu \mathrm{M}$ berberine are still able to carry out DNA synthesis, but cells treated with $100 \mu \mathrm{M}$ berberine remain unable to synthesize DNA. Note that fewer cells in the 25 and $50 \mu \mathrm{M}$ berberine cultures exhibit BrdU labeling than are labeled in the control (no berberine) cultures $(\mathbf{a}-\mathbf{c})$. (p-u) Cells treated with 25,50 or $100 \mu \mathrm{M}$ berberine for $96 \mathrm{~h}$ prior to BrdU labeling. Although cells treated with $25 \mu \mathrm{M}$ berberine are still able to synthesize DNA,

BrdU labeling has been lost from the $50 \mu \mathrm{M}$ berberine cultures.

The $100 \mu \mathrm{M}$ berberine culture remains unlabeled. All micrographs are the same magnification; bar in (u) represents $20 \mu \mathrm{m}$
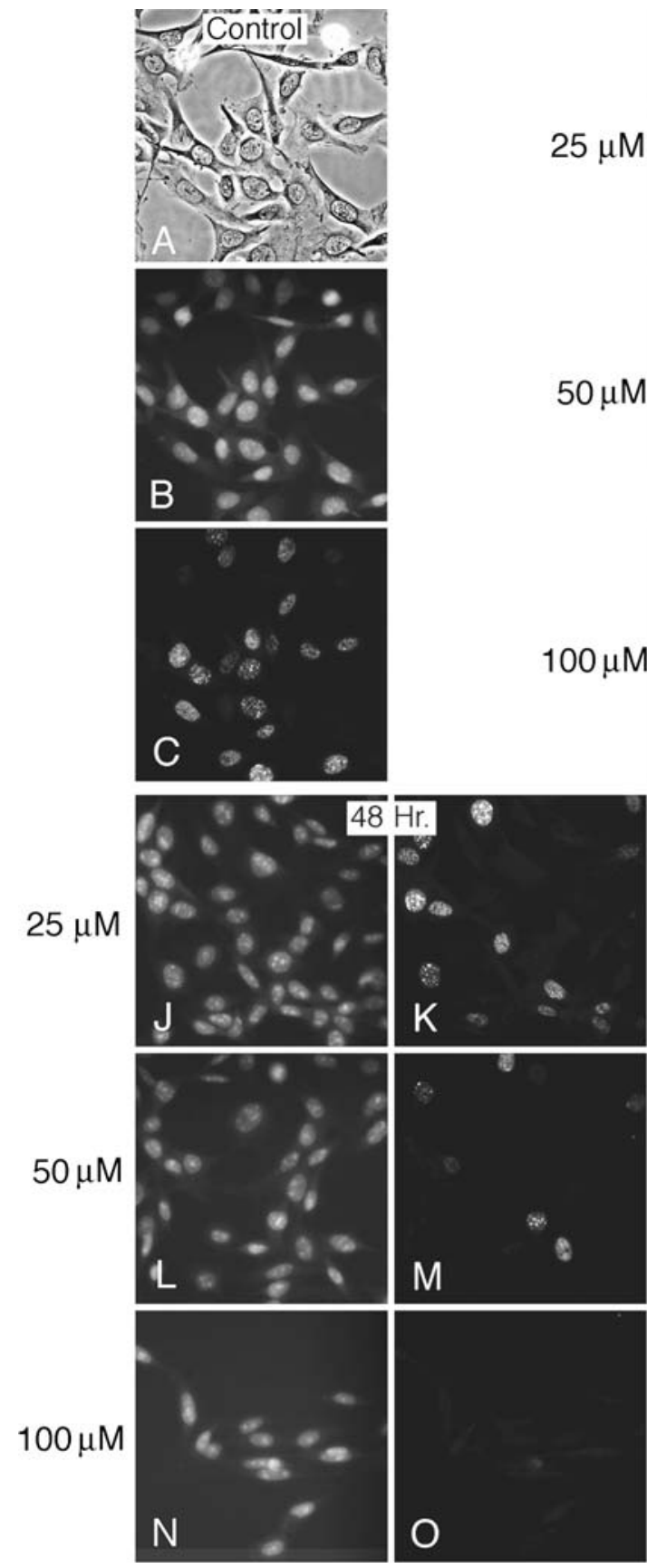
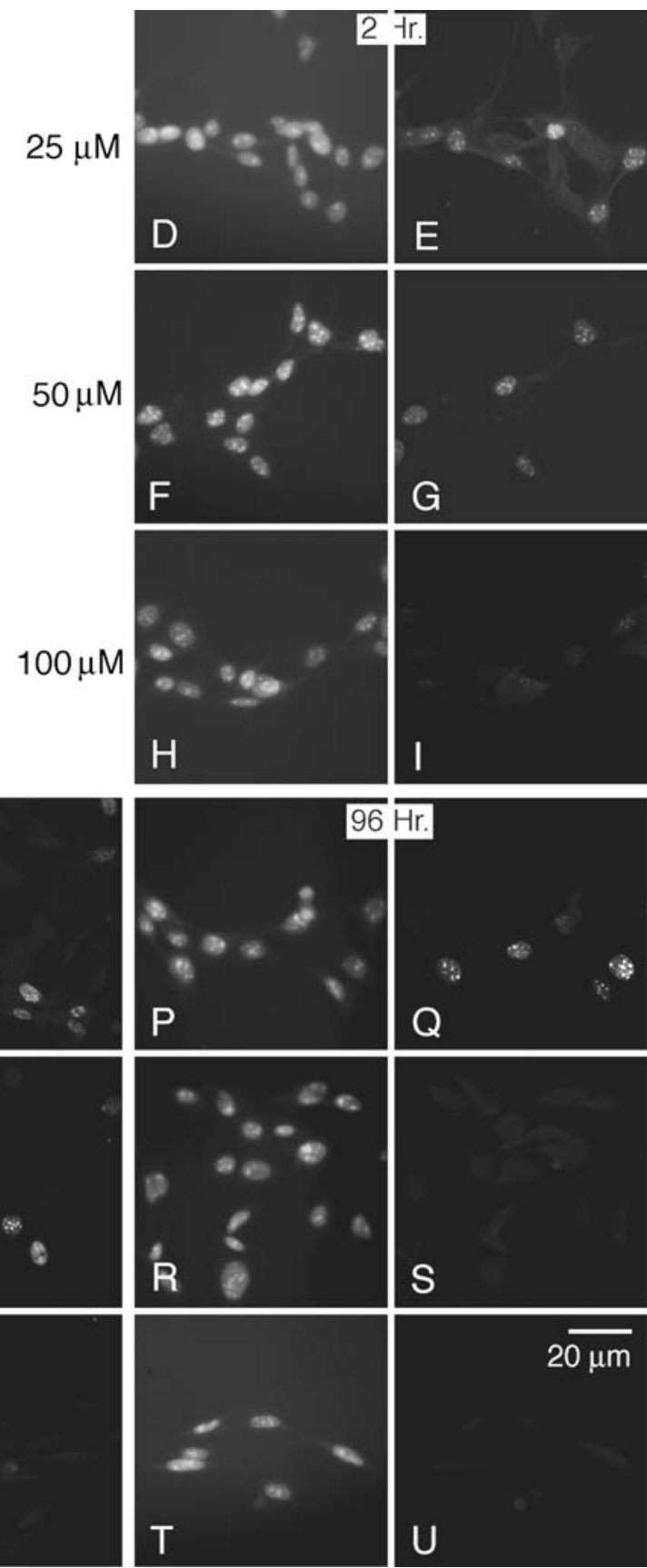

using isolated liver mitochondria, and have found that berberine primarily affects complex I function, inhibiting respiration and increasing oxidative stress (Pereira et al. submitted).

A number of studies have reported various effects of berberine on cell cycle progression in different types of cancer cell lines. G1 arrest has been reported for epidermal [12] and prostate [2] carcinoma cells. However, berberine can arrest gastric carcinoma [11] and HL-60 leukemia cells in G2/M [39]. In contrast, berberine has been reported to have little effect on cell cycle traverse in U937 leukemia and B16 melanoma cell lines [40]. Our results with K1735-M2 melanoma cells show that the exact nature of cell cycle perturbation depends on the concentration of berberine used, with lower concentrations resulting in G1 arrest, and higher concentrations leading to a G2 arrest. Consequently, the conflicting information in the literature may reflect in part the different concentrations of berberine used in different studies. In addition, different cells lines exhibit significantly different sensitivities to this alkaloid. For example, almost two orders of magnitude difference in $\mathrm{IC}_{50}$ values were reported in the same study for leukemia and melanoma cell lines [40].

Expression of key cell cycle regulatory molecules appears to be altered in response to berberine exposure. 
Fig. 10 Epifluorescence micrographs showing the effects of berberine on mitochondrial morphology and membrane polarization in two different melanoma cell lines. K1735-M2 mouse and WM793 human melanoma cells were treated with vehicle only (0.1\% DMSO, control) or $25 \mu \mathrm{M}$ berberine for $6 \mathrm{~h}$ prior to labeling nuclei with Hoechst, and mitochondria with the polarization-dependent probe TMRM. Note that berberine treatment causes mitochondrial fragmentation and a reduction in polarization (fluorescence intensity) in both melanoma cell lines. Other than these mitochondrial effects, the cells look morphologically very similar to the controls
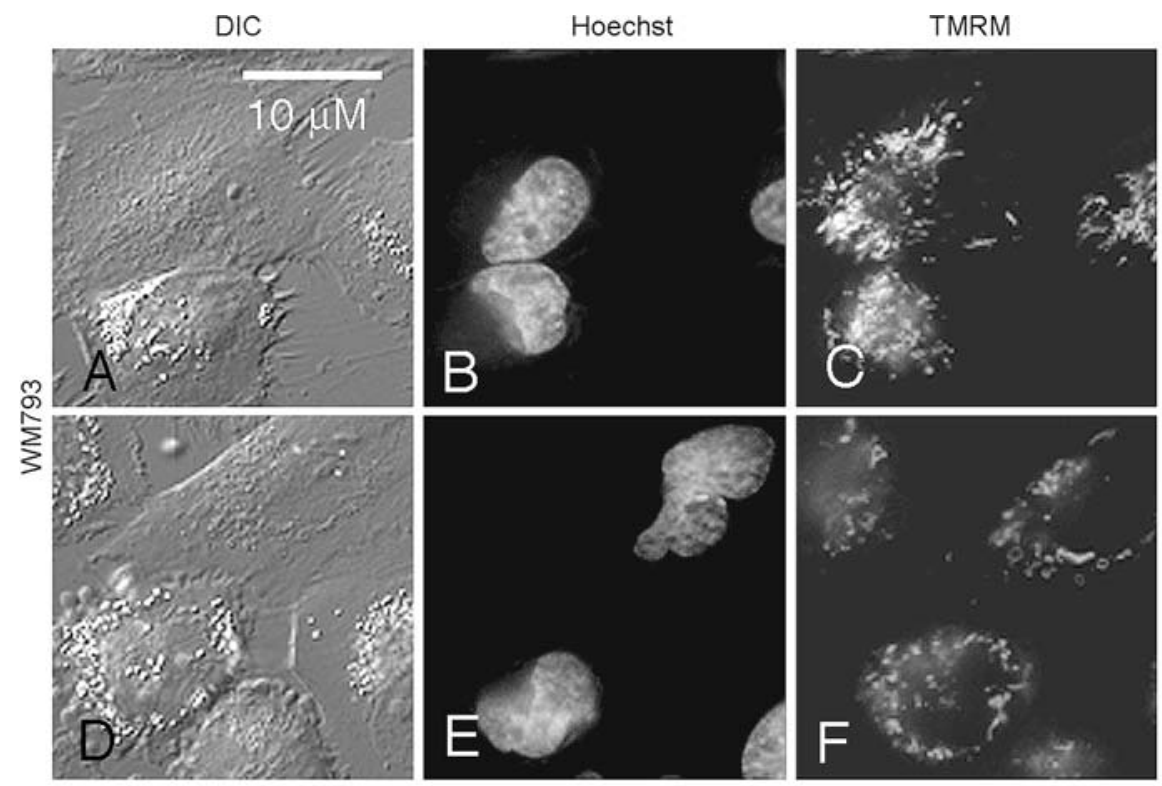

Control
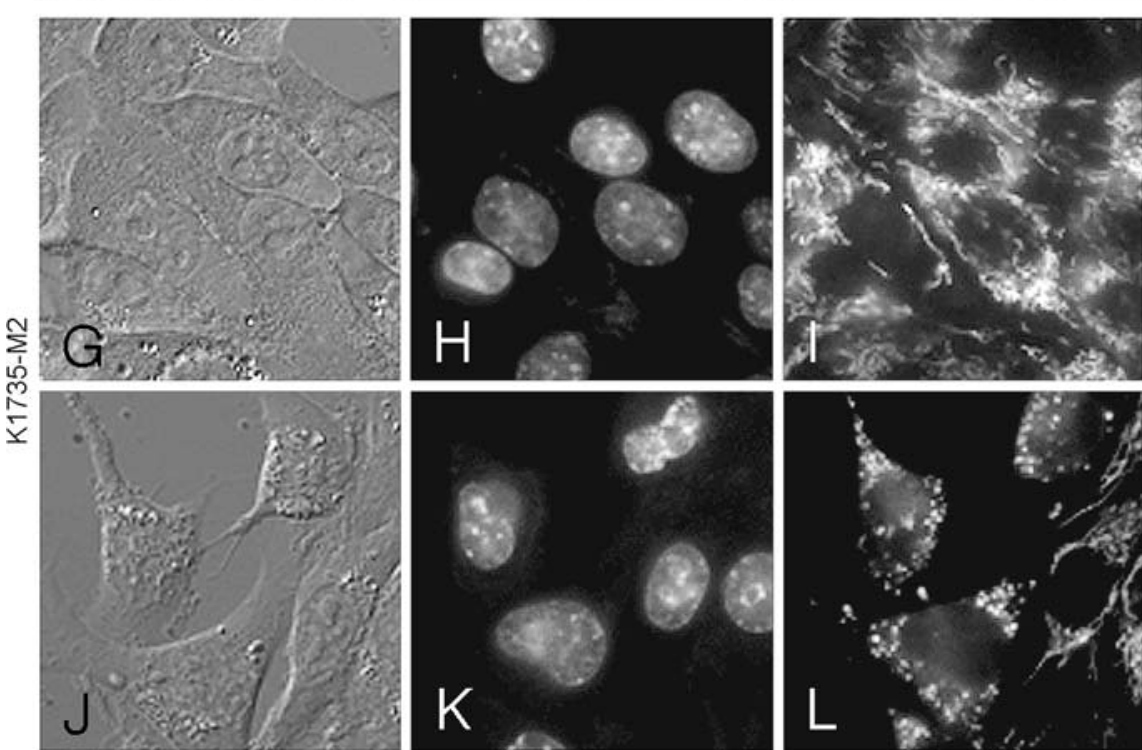

Control
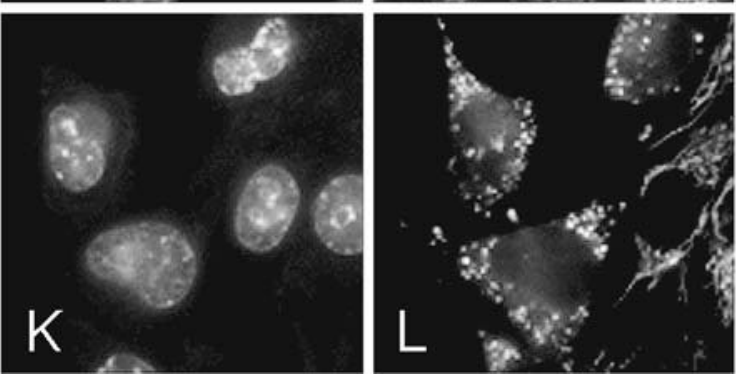

$25 \mu \mathrm{M}$

Berberine
Down regulation of cyclins D1, D2 and E, and CDKs 2, 4 and 6, together with increased expression of the CKIs p21 and p27 were suggested to be responsible for the G1 arrest observed in berberine-treated prostate carcinoma cells [2]. In the studies showing G2/M arrest in promyelocytic leukemia and gastric carcinoma cells, it was found that the expression of cyclin B and CDK1 were decreased, while the levels of Wee1 were increased. The authors concluded that the G2/M arrest was caused by these effects of berberine on these molecules [39].

Early studies showed that low glucose levels can lead to a G1 arrest [41], as can interfering with mitochondrial function [42]. A mechanistic link between ATP depletion and cell cycle arrest has recently been obtained by the demonstration that glucose limitation can activate the energy sensor AMPK, as well as p53 [43]. In Drosophila embryos, a 60\% reduction in ATP levels resulting from a mutation in a mitochondrial electron transport chain protein allows cells to survive, grow, and differentiate, but blocks cell division via activation of AMPK. AMPK activation activates p53, reduces levels of cyclin E, and results in a G1 arrest [44]. In addition, reducing ATP levels with mitochondrial poisons also may result in a down-regulation of D-type cyclins, further contributing to a G1 arrest [45]. We propose that the increase in the percentage of M2 cells in G1 following lower doses ( 25 and $50 \mu \mathrm{M})$ of berberine reflect the effects of mitochondrially-concentrated berberine on respiratory function, resulting in lower ATP levels and activation of a G1 ATP checkpoint. This proposal is supported by the finding that ATP levels are reduced in cells treated with berberine (Pereira et al. submitted).

Berberine has been reported to inhibit DNA synthesis [46] and induce S-phase cell cycle arrest [11]. We found 
that in M2 melanoma cells, short-term exposure to berberine had little direct effect on DNA synthesis except at very high doses. The ability of high concentrations $(100 \mu \mathrm{M})$ of berberine to arrest DNA synthesis was maintained for extended periods of time, namely, up to 4 days of treatment, the longest time point examined in this study. Because berberine is a DNA-binding compound, we presume that the rapid inhibition of DNA synthesis by high concentrations of berberine reflects altered replication across berberine-bound DNA, or inhibition of the replication complex itself. In contrast, lower concentrations of berberine ( 25 and $50 \mu \mathrm{M})$ do not immediately block DNA synthesis, but instead exhibit a delayed effect on BrdU uptake. BrdU-labeled cells could be found at all time points in cultures treated with $25 \mu \mathrm{M}$ berberine, but the number of labeled cells appeared to be diminished with extended drug exposure times ( $24 \mathrm{~h}$ and longer). Notably, BrdU uptake could be completely suppressed in cultures incubated in $50 \mu \mathrm{M}$ berberine, but this effect took between 48 and $96 \mathrm{~h}$ to occur. These observations, together with the flow cytometry data, suggest that lower doses of berberine $(<100 \mu \mathrm{M})$ allow cells to progress through S-phase, but subsequent entry into $S$ is inhibited due to cell cycle arrest. At low concentrations of berberine, this arrest may reflect mitochondrial perturbation and initiation of the G1 "ATP checkpoint" described above. Higher concentrations of berberine resulted in a G2/M arrest, which is suggestive of a DNA damage/p53 activation response [47, 48]. Although we did not directly assay DNA damage in this study, previous workers have presented evidence for berberine-induced DNA damage and p53 activation $[11,38,46]$.

Our results demonstrate that different concentrations of berberine lead to distinct cellular responses that are correlated with specific cellular localization patterns. Interestingly, an earlier study also correlated differences in berberine concentration and distribution with the responses of Balb/c 3T3 cells. In that study, $100 \mu \mathrm{M}$ berberine was mostly located in the cytoplasm and induced a G2/M arrest (similar to our results), while $200 \mu \mathrm{M}$ was concentrated in the nucleus and triggered apoptosis [25]. Together, these data suggest that the following multiphase model of action can be proposed: low concentrations of berberine are selectively accumulated by mitochondria, resulting in altered mitochondrial function, a reduction in ATP synthesis, activation of a G1 energy checkpoint, and consequently a slowing or arrest of cell proliferation. Higher concentrations of berberine saturate the mitochondrial binding capacity and subsequently accumulate in the cytoplasm and nucleus, and directly interfere with DNA synthesis. The nuclear effects of high concentrations of berberine may activate p53 and Wee1, and inhibit cyclin B, leading to a G2 block prior to entry into M-phase. Very high concentrations may result in cell cycle perturbation and/or DNA damage sufficient to trigger apoptosis. It therefore appears that berberine would function more as a mitochondriotropic and cytostatic agent than a nuclear-damaging and cytotoxic agent at clinically relevant concentrations. It is possible that these multiphase effects resulting from dose-dependent patterns of intracellular berberine localization can be exploited in the future to treat cell proliferative diseases where arrest of cell growth instead of induction of cell death is an acceptable treatment outcome, as well as in the ongoing search for natural products that synergize with current standard-of-care chemotherapeutics.

Acknowledgments This work was supported by a gift from the Ladies Auxiliary of the Veterans of Foreign Wars, and by the Portuguese Luso-American Foundation. The authors wish to thank Dr Amy Greene for her generous help with flow cytometry.

\section{References}

1. Vogel VJ (1990) American Indian medicine, University of Oklahoma Press, Norman

2. Mantena S, Sharma S, Katiyar S (2006) Berberine, a natural product, induces G1-phase cell cycle arrest and caspase-3-dependent apoptosis in human prostate carcinoma cells. Mol Cancer Ther 5:296-308

3. Maiti M, Kumar GS (2006) Molecular aspects on the interaction of protoberberine, benzophenanthridine, and aristolochia group of alkaloids with nucleic acid structures and biological perspectives. Med Res Rev (epub ahead of print)

4. Grycova L, Dostal J, Marek R (2007) Quaternary protoberberine alkaloids. Phytochemistry 68:150-175

5. Dworkin N (1999) Where have all the flowers gone?--herbal supplements threaten some herb species. Vegetarian Times Sept

6. Hwang J-M, Kuo H-C, Tseng T-H, Liu J-Y, Chu C-Y (2006) Berberine induces apoptosis through a mitochondria/caspases pathway in human hepatoma cells. Mol Toxicol 80:62-73

7. Inoue K, Kulsum U, Chowdhury SA, Fujisawa S, Ishihara M, Yokoe I, Sakagami H (2005) Tumor-specific cytotoxicity and apoptosisinducing activity of berberines. Anticancer Res 25:4053-4059

8. Jantova S, Cipak L, Cernakova M, Kost'alova D (2003) Effect of berberine on proliferation, cell cycle and apoptosis in HeLa and L1210 cells. J Pharm Pharmacol 55:1143-1149

9. Jantova S, Cipak L, Letasiova S (2007) Berberine induces apoptosis through a mitochondrial/caspase pathway in human promonocytic U937 cells. Toxicol In Vitro 21:25-31

10. Lin C-C, Kao S-T, Chen G-W, Ho H-C, Chung J-G (2006) Apoptosis of human leukemia HL-60 cells and murine leukemia WEHI3 cells induced by berberine through the activation of caspase- 3 . Anticancer Res 26:227-242

11. Lin JP, Yang JS, Lee JH, Hsieh WT, Chung JG (2006) Berberine induces cell cycle arrest and apoptosis in human gastric carcinoma SNU-5 cell line. World J Gastroenterol 12:21-28

12. Mantena SK, Sharma SD, Katiyar SK (2006) Berberine inhibits growth, induces G1 arrest and apoptosis in human epidermoid carcinoma A431 cells by regulatin Cdki-Cdk-cyclin cascade, disruption of mitochondrial membrane potential and cleavage of caspace-3 and PARP. Carcinogenesis (epub ahead of print)

13. Skehan P, Storeng R, Scudiero D, Monks A, McMahan J, Vistica D, Warren JT, Bokesch H, Kenny S, Boyd MR (1990) New colorimetric cytotoxicity assay for anticancer-drug screening. J Natl Cancer Inst 82:1107-1112 
14. Holy J, Lamont G, Perkins E (2006) Disruption of nucleocytoplasmic trafficking of cyclin D1 and topoisomerase II by sanguinarine. BMC Cell Biol 7:13-25

15. Berlin G, Enerback L (1983) Fluorescent berberine binding as a marker of secretory activity in mast cells. Int Arch Allergy Appl Immunol 71:332-339

16. Dimlich RV, Meineke HA, Reilly FK, McCuskey RS (1980) The fluorescent staining of heparin in mast cells using berberine sulfate: compatibility with paraformaldehyde or $o$-phthalaldehyde induced fluorescence and metachromasia. Stain Technol 55:217223

17. Reyes R, Ramirez G, Delgado NM (2004) Fluorescent berberine binding as a marker of internal glycosaminoglycans sulfate in bovine oocytes and sperm cells. Arch Androl 50:327-332

18. Curtis SK, Cowden RR (1981) Four fluorochromes for the demonstration and microfluoreometric estimation of RNA. Histochemistry $72: 39-48$

19. Gong GQ, Zong ZX, Song YM (1999) Spectrofluorometric determination of DNA and RNA with berberine. Spectrochim Acta A Mol Biomol Spectrosc 55A:1903-1907

20. Molero ML, Stockert JC (1981) Fluorescence reaction of chromatin and basophilic cytoplasm by berberine sulfate. Cell Mol Biol Incl Cyto Enzymol 27:523-525

21. Talwalkar SS, Vaidya AB, Godse C, Vaidya A, Vaidya R (2005) Plasmodium DNA fluoresces with berberine: a novel approach for diagnosis of malarial parasites. Am J Clin Pathol 124:408-412

22. Borodina VM, Zelenin AV (1977) Fluorescence microscopy demonstration of mitochondria in tissue culture cells using berberine. Tsitologiia 19:1067-1068

23. Mikes V, Dadak V (1983) Berberine derivatives as cationic fluorescent probes for the investigation of the energized state of mitochondria. Biochim Biophys Acta 723:231-239

24. Slaninova I, Taborska E, Bochorakova H, Slanina J (2001) Interaction of benzo[c]phenanthridine and protoberberine alkaloids with animal and yeast cells. Cell Biol Toxicol 17(1):51-63

25. Yang IW, Chou CC, Yung BY (1996) Dose-dependent effects of berberine on cell cycle pause and apoptosis in Balb/c 3T3 cells. Naunyn Schmiedebergs Arch Pharmacol 354:102-108

26. Min YD, Yang MC, Lee KH, Kim KR, Choi SU, Lee KR (2006) Protoberberine alkaloids and their reversal activity of P-gp expressed multidrug resistance (MDR) from the rhizome of Coptis japonica Makino. Arch Pharm Res 29:757-761

27. He L, Liu GQ (2002) Interaction of multidrug resistance reversal agents with $P$-glycoprotein ATPase activity on blood-brain barrier. Acta Pharmacol Sin 23:423-429

28. Lin HL, Liu TY, Wu CW, Chi CW (1999) Berberine modulates expression of $m d r l$ gene product and the responses of digestive track cancer cells to paclitaxel. Br J Cancer 81:416-422

29. Shitan N, Tanaka M, Terai K, Ueda K, Yazaki K (2007) Human MDR1 and MRP1 recognize berberine as their transport substrate. Biosci Biotechnol Biochem 71:242-245

30. Zuo F, Nakamura N, Akao T, Hattori M (2006) Pharmacokinetics of berberine and its main metabolites in conventional and pseudo germ-free rats determined by liquid chromatography/ion trap mass spectrometry. Drug Metab Dispos 34:2064-2072

31. Chen CM, Chang HC (1995) Determination of berberine in plasma, urine and bile by high-performance liquid chromatography. $\mathrm{J}$ Chromatogr B 665:117-123
32. Pan JF, Yu C, Zhu DY, Zhang H, Zeng JF, Jiang SH, Ren JY (2002) Identification of three sulfate-conjugated metabolites of berberine chloride in healthy volunteer's urine after oral administration. Acta Pharmacol Sin 23:77-82

33. Hoshi A, Ikekawa T, Ikeda Y, Shirakawa S, Iigo M (1976) Antitumor activity of berberrubine derivatives. Gann 67:321-325

34. Kobayashi Y, Tamashita Y, Fujii N, Takaboshi K, Kawakami T, Kawamura M, Mizukami T, Nakano H (1995) Inhibitors of DNA topoisomerase I and II isolated from the Coptis rhizomes. Planta Med 61:414-418

35. Makhey D, Gatto B, Yu C, Liu A, Liu LF, LaVoie E, Edmond J (1995) Protoberberine alkaloids and related compounds as dual inhibitors of mammalian topoisomerase I and II. Med Chem Res $5: 1-12$

36. Letasiova S, Jantova S, Muckova M, Theiszova M (2005) Antiproliferative activity of berberine in vitro and in vivo. Biomed Pap Med Fac Univ Palacky Olomouc Czech Repub 149:461-463

37. Barreto MC, Pinto RE, Arrabaca JD, Pavao ML (2003) Inhibition of mouse liver respiration by Chelidonium majus isoquinoline alkaloids. Toxicol Lett 146:37-47

38. Jantova S, Letasiova S, Brezova V, Cipak L, Labaj J (2006) Photochemical and phototoxic activity of berberine on murine fibroblast NIH-3T3 and Ehrlich ascites carcinoma cells. J Photochem Photobiol B 85:163-176

39. Lin C-C, Lin S-Y, Chung J-G, Lin J-P, Chen C-W, Kao S-T (2006) Down-regulation of cyclin B1 and up-regulation of Wee 1 by berberine promotes entry of leukemia cells into the G2/M-phase of the cell cycle. Anticancer Res 26:1097-1104

40. Letasiova S, Jantova S, Cipak L, Muckova M (2006) Berberineantiproliferative activity in vitro and induction of apoptosis/necrosis of the U937 and B16 cells. Cancer Lett 239:254-262

41. Holley RW, Kiernan JA (1974) Control of the initiation of DNA synthesis in 3T3 cells: low-molecular weight nutrients. Proc Natl Acad Sci USA 71:2942-2945

42. VanDenBogert BC, Kernebeek Gv, Leij Ld, Kroon AM (1986) Inhibition of mitochondrial protein synthesis leads to proliferation arrest in the G1-phase of the cell cycle. Cancer Lett 32:41-51

43. Jones RG, Plas DR, Kubek S, Buzzai M, Mu J, Xu Y, Birnbaum MJ, Thompson CB (2005) AMP-activated protein kinase induces a p53-dependent metabolic checkpoint. Mol Cell 18:283-293

44. Mandal S, Guptan P, Owusu-Ansah E, Banerjee U (2006) Mitochondrial regulation of cell cycle progression during development as revealed by the tenured mutation in Drosophila. Dev Cell 9:843-854

45. Gemin A, Sweet S, Preston TJ, Singh G (2005) Regulation of the cell cycle in response to inhibition of mitochondrial generated energy. Biochem Biophys Res Commun 332:1122-1132

46. Letasiova S, Jantova S, Miko M, Ovadekova R, Horvathova M (2006) Effect of berberine on proliferation, biosynthesis of macromolecules, cell cycle and induction of intercalation with DNA, dsDNA damage and apoptosis in Ehrlich ascites carcinoma cells. J Pharm Pharmacol 58:263-270

47. Bunz F, Dutriaux A, Lengauer C, Waldman T, Zhou S, Brown JP, Sedivy FM, Kinzler KW, Vogelstein B (1998) Requirement for p53 and p21 to sustain G2 arrest after DNA damage. Science 282:1497-1501

48. Taylor WR, Stark GR (2001) Regulation of the G2/M transition by p53. Oncogene 20:1803-1815 